Gastrostomi Tüpü Yerleştirilen Çocuklarda Perkütan Endoskopik Gastrostomi ve Açık Gastrostominin Güvenlik Profillerinin Karşılaştırılması

\title{
Comparison of Safety Profile of Percutaneous Endoscopic Gastrostomy \& Open Gastrostomy in Children Undergoing Gastrostomy Tube Insertion
}

Gülseren Yılmaz', Günsel Kutluk², Osman Esen³, Ziya Salihoğlu4

1Sağlık Bilimleri Üniversitesi, Tıp Fakültesi, Anesteziyoloji ve Reanimasyon Ana Bilim Dalı, Kanuni Sultan Süleyman Hastanesi, İstanbul 2Sağlık Bilimleri Üniversitesi, Tıp Fakültesi, Pediyatrik Gastroenteroloji Ana Bilim Dalı, Kanuni Sultan Süleyman Hastanesi, İstanbul 3İstanbul Onkoloji Hastanesi, Anesteziyoloji ve Reanimasyon, İstanbul

4İstanbul Üniversitesi, Cerrahpaşa Tıp Fakültesi, Anesteziyoloji ve Reanimasyon Ana Bilim Dalı, İstanbul

\section{$\ddot{O} Z$}

GIRIŞ ve AMAÇ: Perkütan endoskopik gastrostomi (PEG) ve açık gastrostominin $(A G)$ avantaj, dezavantaj ve erken komplikasyonlarını karşılaştıran güncel çalışma sayısı azdır. Bu çalışma iki yöntemin erken sonuçlarını karşılaştırmayı amaçlamaktadır.

YÖNTEM ve GEREÇLER: Gastrostomi tüpü yerleştirilen 70 pediatrik hastaya ait demografik bilgiler, uygulanan girişimler ve komplikasyonlar hastan bilgi işlem sisteminden derlendi. Hastalar sedasyon altında PEG uygulanan (30 hasta) ya da genel anestezi altında AG uygulananlar (40 hasta) olmak üzere iki gruba ayrldd.

BULGULAR: AG uygulanan hastalarda PEG uygulananlarla klyaslandiğında toplam major komplikasyon oranı daha fazlaydl (\% $28^{\prime}$ e karşı \% 7, p=0.032). Bronkospazm (\% 25'e karşı \% 7, $p=0.035$ ) ve inatraoperatif aritmiler (\% 17 ' e karşı $\% 3, p=0.049)$ AG grubunda PEG grubuna göre daha siktı. AG uygulanan hastalarda hastanede yatış süresi PEG uygulanan hastalara klyasla anlaml olarak daha yüksekti (3.8 \pm 1.4 güne karşı $1.2 \pm 0.5$ gün, $p<0.001)$.

TARTIŞMA ve SONUÇ: Gastorostomi tüpü yerleştirilen hastalarda PEG ile tüp yerleştirilmesi AG ile tüp yerleştirilmesine klyasla azalmış intraoperatif komplikasyona oranı, azalmıs postoperatif komplikasyon oranı ve daha kısa hastane yatış süresi ile iliş̧ilidir. Çalışmamızın sonuçları, sedasyon altında PEG ile gastrostomi tüpü yerleştirilmesinin genel anestezi altında AG ile tüp yerleştirilmesinden daha güvenli olduğunu göstermektedir.

Anahtar Kelimeler: PEG, açık gastrostomi, çocuk, komplikasyon

\begin{abstract}
INTRODUCTION: Current data comparing advantages, disadvantages and early post interventional complications of percutaneous endoscopic gastrostomy (PEG) and open gastrostomy $(O G)$ is limited. The present study aimed to compare the early post interventional results of patients undergoing PEG or $O G$ tube insertion.
\end{abstract}

METHODS: Retrospective data regarding the demographic features, interventions, and complications of 70 children undergoing gastrostomy tube insertion were obtained from institutions digital database. Patients were divided into two research groups according to the technique used in gastrostomy tube placement: group 1 consisted of 40 patients undergoing $O G$ tube placement under general anesthesia and group 2 consisted of 30 patients undergoing PEG tube placement with sedation.

RESULTS: Overall major complication rate was significantly higher in OG patients than PEG patients $(28 \% \mathrm{vs} .7 \%$, $p=0.032)$. Bronchospasm (25\% vs. $7 \%, p=0.035)$ and intraoperative arrhythmias (17\% vs. $3 \%, p=0.049)$ were also more prevalent in patients receiving $O G$ tube placement compared to those receiving PEG tube placement. Length of hospital stay was longer in $O G$ group than that of the PEG group $(3.8 \pm 1.4$ days vs. $1.2 \pm 0.5$ days, $p<0.001)$.

DISCUSSION AND CONCLUSION: In children undergoing gastrostomy tube placement, PEG tube insertion compared to $O G$ tube insertion, is associated with decreased frequency of intraoperative complications, postoperative major complications and shorter hospital stay. Our results show that PEG technique with sedation provides better safety profile than $O G$ in children undergoing gastrostomy tube insertion.

Keywords: PEG, open gastrostomy, children, complication

İletişim / Correspondence:

Dr. Gülseren Yılmaz

Sağllk Bilimleri Üniversitesi, Tip Fakültesi, Anesteziyoloji ve Reanimasyon Ana Bilim Dalı, Kanuni Sultan Süleyman Hastanesi, İstanbul E-mail: drgülseren83@gmail.com

Başvuru Tarihi: 18.06.2019

Kabul Tarihi: 22.02.2020 


\section{INTRODUCTION}

Gastrostomy is an intervention in which the eosophagus is by-passed by a tube inserted directly into the stomach through an opening in the anterior abdominal wall. Primary purpose of this procedure is to provide a safe route for long-term enteral feeding of the child with swallowing disorder. A wide spectrum of clinical conditions including neurological impairment with the inability to swallow or dysphagia, craniofacial abnormalities, malignancies with malnutrition, recurrent documented aspiration and chronic diseases proceeding with wasting and malnutrition constitute an indication for gastrostomy tube placement (1). European Society for Clinical Nutrition and Metabolism (ESPEN) guidelines on artificial enteral nutrition recommend placement of gastrostomy tube in patients dependent of supplementary artificial enteral nutrition exceeding 2 weeks (2).

Children comprise a special population for gastrostomy interventions. Previous data indicate that in the United States, about $4 \%$ of patients requiring percutaneous endoscopic gastrostomy (PEG) are children (3). Percutaneous endoscopic gastrostomy and open gastrostomy (OG) are two common ways of gastrostomy tube placement in children. However, current data comparing advantages, disadvantages and early postinterventional complications of the two techniques is limited. Therefore, the present study aimed to compare the early post-interventional outcomes of patients undergoing PEG or OG tube insertion.

\section{MATERIALS AND METHODS}

All gastrostomy tube placements in children aged 0 to 18 years between February 2014 and March 2018 in our institute (tertiary center) were retrospectively included in this study. All subjects were outpatients underwent surgery or intervention under elective circumstances. Subjects with previous intolerance to local and general anesthetic agents, and those with severe ascites, hemodynamic instability, or active peritonitis, and > ASA Class III were not included in the study. Data regarding the demographic features, interventions, and the complications were obtained from institutions digital records. Patients were divided into two research groups according to the technique used in gastrostomy tube placement: group 1 consisted of 40 patients undergoing open gastrostomy and group 2 consisted of 30 patients undergoing PEG. PEG interventions and $\mathrm{OG}$ procedures were carried out by the same surgical team. Subjects were allocated to $\mathrm{OG}$ in the presence of relative or absolute contraindications for PEG intervention such as active coagulopathy, oropharyngeal or esophagial cancer, prior abdominal surgery, ventral hernia and hepatomegaly or splenomegaly. Informed consent for the use of their medical information was obtained from all parents of subjects included in this study. The study was carried out in accordance with the ethical standards laid down in the 1964 Declaration of Helsinki and its later amendments.

\section{PEG intervention}

PEG procedures were carried out with an Fujinon eosophagogastroduodenoscope under sedation using ketofol administered $20 \mathrm{mg} / 10 \mathrm{~s}$ (1:1 mixture of ketamine $10 \mathrm{mg} / \mathrm{ml}$ and propofol $10 \mathrm{mg} / \mathrm{ml}$ mixed in a 20-ml syringe) until the patient no longer responded to his/her name being called loudly and showed loss of the eyelash reflex. Following the insertion of the gastroscope into the stomach, the air was insufflated gently and the most transluminant point of indentation on the anterior abdominal wall was marked. After having incised the skin for approximately $0.5 \mathrm{~cm}$, a cannula was pushed into the stomach under complete endoscopic visualization. Thereafter, a guidewire was inserted through the cannula, then was snared and drawn out through the mouth together with the gastroscope. An adequate sized PEG tube was then connected to the thread and the thread was pulled from the skin incision pulling the tube into the patient's mouth through the esophagus, to be retained in the stomach by the internal bolster. Afterward, an external bolster was placed loosely on the skin.

\section{Open gastrostomy procedure}

All OG procedures were performed under general anesthesia by experienced pediatric surgeons and all of the patients received prophylactic antibiotic therapy. Following an upper midline incision, purse string sutures were placed on the anterior wall of 
the stomach close to the greater curvature. The gastrostomy tube was drawn through the incision on the abdominal wall and then inserted into the stomach. The stomach was then fixed to the anterior abdominal wall by sutures that traverse the seromuscular layer of the stomach and the peritoneum.

\section{Definition of complications}

The following were defined as major complications: dislodgment or migration of the gastrostomy tube, gastrostomy leaks causing peritonitis, gastric perforation, organ injuries, any fistula formation, hemorrhage and need for recurrent intervention. Other complications not requiring additional intervention such as limited leaks or formation of granulation tissue were defined as minor complications. Any complication occurring at operation room such as bronchospasm, desaturation $(\mathrm{SaO} 2<90 \%)$, supraventricularventricular arrhythmia and hypotension (systolic blood pressure $<90 \mathrm{mmHg}$ or diastolic blood pressure $<60 \mathrm{mmHg}$ ) was defined as intraoperative complication.

\section{Statistical Analysis}

Statistical analyses were carried out using SPSS for Windows, version 19 (SPSS, Chicago, IL, USA). Distribution of the variables was studied with the Kolmogorov-Smirnov test. Continuous variables were given as the mean \pm standard deviation and categorical variables as a percentage. Continuous variables of the two study groups were compared using student t-test. The chi-square test was used for comparison of the categorical variables. Twosided $\mathrm{p} \leq 0.05$ was interpreted as statistically significant.

\section{RESULTS}

A total of 70 children (mean age $62 \pm 35$ months, 40 [57 \%] male) undergoing gastrostomy tube placements were enrolled in this study. Cerebral palsy (44 \%) and Genetic/metabolic diseases $(30 \%)$ were the most common underlying clinical condition for gastrostomy tube placement. Of the study population, 40 children underwent $O G$ and 30 underwent PEG tube insertion. Thirteen (18 $\%)$ of the participants were subject to major complications and 3 patients (4\%) died during the postinterventional/postoperative course.

The two groups were similar for age, gender, height, weight, BMI, and ASA classes (Table 1).

\begin{tabular}{|c|c|c|c|}
\hline & $\begin{array}{l}\text { OG } \\
n=40\end{array}$ & $\begin{array}{l}\text { PEG } \\
n=30\end{array}$ & $\begin{array}{l}p \\
\text { value }\end{array}$ \\
\hline Age, months & $67 \pm 26$ & $55 \pm 33$ & 0.154 \\
\hline Gender, male & $23(57 \%)$ & $17(57 \%)$ & 1.000 \\
\hline Height, cm & $109 \pm 29$ & $113 \pm 26$ & 0.575 \\
\hline Weight, kg & $25 \pm 12$ & $23 \pm 10$ & 0.533 \\
\hline BMI, $\mathrm{kg} / \mathrm{m}^{2}$ & $20.1 \pm 6.7$ & $18.6 \pm 7.2$ & 0.371 \\
\hline \multicolumn{4}{|l|}{ ASA class } \\
\hline I & $21(52.5 \%)$ & $14(46.7 \%)$ & 0.813 \\
\hline II & $15(37.5 \%)$ & $13(43.3 \%)$ & 0.632 \\
\hline III & $4(10 \%)$ & $3(10 \%)$ & 1.000 \\
\hline \multicolumn{4}{|l|}{ Indication } \\
\hline Cerebral palsy, $n$ & $18(45 \%)$ & $13(33 \%)$ & 0.890 \\
\hline $\begin{array}{l}\text { Genetic/metabolic } \\
\text { disease, } \mathbf{n}\end{array}$ & $11(28 \%)$ & $10(33 \%)$ & 0.610 \\
\hline $\begin{array}{l}\text { Gastrointestinal } \\
\text { anomaly, n }\end{array}$ & $5(13 \%)$ & $2(7 \%)$ & 0.690 \\
\hline $\begin{array}{l}\text { Oropharengeal } \\
\text { malformation, } \mathbf{n}\end{array}$ & $2(5 \%)$ & $2(7 \%)$ & 0.766 \\
\hline Others, n & $4(10 \%)$ & $3(10 \%)$ & 1.000 \\
\hline
\end{tabular}

However, the duration of the intervention (56.7 \pm $21.6 \mathrm{~min}$. vs. $22.8 \pm 12.6 \mathrm{~min}, \mathrm{p}<0.001$ ), recovery time ( $28 \pm 11 \mathrm{~min}$. vs. $11 \pm 6 \mathrm{~min} ., \mathrm{p}<0.001)$ and intensive care unit requirement $(25 \%$ vs. $7 \%$, $\mathrm{p}=0.044$ ) were significantly higher in patients undergoing OG compared to those undergoing PEG (Table 2). Minor complication rates were similar in the two groups. However, intraoperative complications including bronchospasm (25\% vs. $7 \%, \mathrm{p}=0.035)$ and suprvantricular/ ventricular arrhythmias (17\% vs. $3 \%, \mathrm{p}=0.049)$ were more prevalent in patients receiving OG tube placement compared to those receiving PEG tube placement. 
Tablo 2. Comparison of interventional features and complications between the PEG and OG tube insertion groups

\begin{tabular}{|c|c|c|c|}
\hline & $\begin{array}{l}\text { OG } \\
n=40\end{array}$ & $\begin{array}{l}\text { PEG } \\
n=30\end{array}$ & $p$ value \\
\hline $\begin{array}{l}\text { Intervention time, } \\
\text { minutes }\end{array}$ & $56.7 \pm 21.6$ & $22.8 \pm 12.6$ & $<0.001$ \\
\hline $\begin{array}{l}\text { Recovery time, } \\
\text { minutes }\end{array}$ & $28 \pm 11$ & $11 \pm 6$ & $<0.001$ \\
\hline ICU requirement, $n$ & $10(25 \%)$ & $2(7 \%)$ & 0.044 \\
\hline \multicolumn{4}{|l|}{$\begin{array}{l}\text { Intraoperative } \\
\text { complications, } n\end{array}$} \\
\hline Bronchospasm, n & $10(25 \%)$ & $2(7 \%)$ & 0.035 \\
\hline Desaturation, $\mathbf{n}$ & $2(5 \%)$ & $1(3 \%)$ & 0.733 \\
\hline SVA/VA, n & $7(17 \%)$ & $1(3 \%)$ & 0.049 \\
\hline Hypotension, n & $6(15 \%)$ & $1(3 \%)$ & 0.087 \\
\hline Minor complications, $\mathbf{n}$ & $6(15 \%)$ & $9(26 \%)$ & 0.130 \\
\hline Major complications, $\mathbf{n}$ & $11(28 \%)$ & $2(7 \%)$ & 0.032 \\
\hline Dislodgement, n & $3(8 \%)$ & $0(0 \%)$ & 0.125 \\
\hline Leakage, $n$ & $4(10 \%)$ & $1(3 \%)$ & 0.284 \\
\hline $\begin{array}{l}\text { Recurrent } \\
\text { intervention, } n\end{array}$ & $4(10 \%)$ & $1(3 \%)$ & 0.284 \\
\hline Death, $n$ & $3(8 \%)$ & $0(0 \%)$ & 0.125 \\
\hline LOS, days & $3.8 \pm 1.4$ & $1.2 \pm 0.5$ & $<0.001$ \\
\hline \multicolumn{4}{|c|}{$\begin{array}{l}\text { Data are presented as mean } \pm \text { standard deviation. ICU: intensive care } \\
\text { unit, LOS: length of stay, OG: open gastrostomy, PEG: percutaneous } \\
\text { endoscopic gastrostomy, SVA/VA: supraventricular arrhythmia / } \\
\text { ventricular arrythmia }\end{array}$} \\
\hline
\end{tabular}

Although major complications including gastrostomy tube migration or dislodgement, leakage or need for recurrent intervention were similar in the two study groups, overall major complication rate was significantly higher in OG patients than PEG patients ( $28 \%$ vs. $7 \%, \mathrm{p}=0.032$ ). Length of hospital stay was also significantly higher in OG group compared to PEG group $(3.8 \pm 1.4$ days vs. $1.2 \pm 0.5$ days, $\mathrm{p}<0.001)$. Although inhospital death was higher in OG group, this difference did not reach statistical significance ( 8 $\%$ vs. $0 \%, \mathrm{p}=0.125)$. The mortality in the $\mathrm{OG}$ group (3 subjects) was associated with intraoperative bleeding.

\section{DISCUSSION}

The present study demonstrates that the frequency of postoperative major complications and intraoperative complications are higher in patients receiving OG tube insertion compared to those receiving PEG tube insertion. In addition, duration of the intervention and frequency of intraoperative complications and length of hospital stay are significantly lower in those undergoing PEG tube placement.

In children with a variety of underlying clinical conditions such as neurological impairment, shortgut syndrome, nutritional requirement in children with malignancies or other chronic medical conditions often need long-term enteral feeding (4).

Gastric feeding is the most common type of enteral feeding. Approach to insert the gastrostomy tube might be achieved by adoption of endoscopy, radiological imaging, or open and laparoscopic surgical techniques. PEG, which has been introduced in 1980 by Gauderer, has currently become the modality of choice for inserting a gastrostomy tube and is garnering increasing attention due to the less invasive nature and the low cost of the intervention (5). Open gastrostomy tube placement is another common procedure performed to create a pathway for enteral feeding which is traditionally preferred by pediatric surgeons by means of the theoretical benefits of the procedure in reducing potential complications of gastric tube replacement (6).

Several studies have shown that both techniques have advantages and drawbacks $(7,8)$. PEG is less invasive and less time consuming compared to OG, however, it is also associated with a high frequency of major complications including gastrostomy leaks causing peritonitis, gastric perforation, gastrocolocutaneous fistula, metastatic seeding, colic injuries and small bowel injuries (9). Although OG is more time consuming and more invasive, direct visualization of the stomach during the procedure provides a more optimal tube placement and accordingly fewer complications associated with the intervention (10). 
While application of PEG in small infants $<2$ $\mathrm{kg}$ is somewhat troubling due to the size of the endoscopes used, OG approach is more challenging in obese individuals and in children with a less mobile stomach, due to difficulties in completely delivering the stomach and the potential untoward effects of excessive traction which can result in gastric injuries.

Studies comparing the two techniques for gastrostomy tube placement revealed controversial results concerning the safety of the procedures. The major complication rate for OG varies between 2.9 $\%$ and $9.1 \%$ depending on the technique used and the population enrolled in these studies (11). Major complication rates for PEG tube placement including early tube dislodgement and gastrocolic fistula, organ injury, cutaneous leaks are comparable to OG with an overall complication rate of varying between $2.1 \%$ to $7.3 \%$. In one of the previous studies conducted on 63 consecutive neurologically impaired children requiring a feeding gastrostomy, Cameron et al. compared the minor and major complication rates following PEG or open gastrostomy tube placemnt and found $9 \%$ major complication rate in open gastrostomy arm compared to no complications in PEG arm (12). Recently, Ackroyd and colleagues compared the safety of the two procedures 98 children undergoing gastrostomy tube insertion and found that an overall rate of major complication rate of $10.2 \%$ for the endoscopic technique and $8.6 \%$ for the open technique (13). In contrast to their findings, Lintula et al. found similar intraoperative, early-onset and late onset complication rates for PEG and open gastrostomy in 69 children undergoing gastrostomy tube placement (14). More recently Liu et. al compared the safety of laparoscopic, open and PEG techniques in 369 children undergoing gastrostomy tube placement. In that study, the authors reported that the incidence of leakage -the most frequent major complication in that study- was significantly lower in patients undergoing PEG and laparoscopic gastrostomy compared to patients undergoing open gastrostomy (15). The variations in major complication rates reported in the aforementioned trials might be associated with study designs and populations enrolled in the trials. Nevertheless, these results indicate that the safety profile of PEG tube insertion compared to $\mathrm{OG}$ tube insertion appears more favorable.

Our results favoring PEG tube insertion concerning the major complication rates are consistent with the majority of the previous studies (16). Similar to the findings reported by Liu et al., we found that leakage, one of the most frequent major complications of gastrostomy tube placement, was less prevalent in patients undergoing PEG tube insertion. In addition rate of intraoperative complications including bronchospasm was also less prevalent in PEG patients. The favorable outcome of PEG compared to OG tube insertion might be a result of the sedation employed in PEG tube insertion. In addition, shorter intervention time and fewer intraoperative complications acquired with PEG tube placement give rise to the thought that PEG tube placement might be more comfortable and costless compared to OG tube placement which is also closely related to enhanced recovery following surgery. Moreover, intraoperative complications, particularly those deteriorating hemodynamic stability including supraventricular or ventricular arrhythmias and intraoperative hypotension were observed only in one patient in patients undergoing PEG tube placement indicating a more predictable and stable intraoperative course.

The present study has some limitations to be mentioned. First, this study is limited by the retrospective nature and therefore might be limited by precise documentation in the medical records. Second, we were able to collect data only for inhospital course and could not provide information regarding further complications. Lastly, we could not present data regarding the costs of the two gastrostomy tube insertion techniques due to the insufficiency of accurate information recorded in the institutions' database concerning the drugs and devices used in these procedures.

\section{CONCLUSION}

In children undergoing gastrostomy tube placement, PEG tube insertion compared to $\mathrm{OG}$ tube insertion, is associated with decreased frequency of intraoperative complications, postoperative major complications and shorter 
hospital stay. Our results show that PEG technique with sedation provides better safety profile than OG in children undergoing tube insertion. We consider that PEG tube placement is still a safe and effective way of obtaining enteral feeding access in the pediatric population.

Funding: This research received no external funding.

Acknowledgments: The authors declare no competing interest.

Conflicts of Interest: The authors declare no conflict of interest

\section{REFERENCES}

1. El-Matary W. Percutaneous endoscopic gastrostomy in children. Can J Gastroenterol. 2008;22(12):993-8.

2. Loser C, Aschl G, Hebuterne X, Mathus-Vliegen EM, Muscaritoli M, Niv $\mathrm{Y}$, et al. ESPEN guidelines on artificial enteral nutrition-percutaneous endoscopic gastrostomy (PEG). Clin Nutr. 2005;24(5):848-61.

3. Gauderer MW. Percutaneous endoscopic gastrostomy and the evolution of contemporary long-term enteral access. Clin Nutr. 2002;21(2):103-10.

4. Akay B, Capizzani TR, Lee AM, Drongowski RA, Geiger JD, Hirschl RB, et al. Gastrostomy tube placement in infants and children: is there a preferred technique? Journal of pediatric surgery. 2010;45(6):1147-52.

5. Goretsky MF, Johnson N, Farrell M, Ziegler MM. Alternative techniques of feeding gastrostomy in children: a critical analysis. J Am Coll Surg. 1996;182(3):233-40.

6. Wollman B, D'Agostino HB, Walus-Wigle JR, Easter DW, Beale A. Radiologic, endoscopic, and surgical gastrostomy: an institutional evaluation and meta-analysis of the literature. Radiology. 1995;197(3):699-704.

7. Gale R, Namestnic J, Singer P, Kagan I. Caloric Requirements of Patients With Brain
Impairment and Cerebral Palsy Who Are Dependent on Chronic Ventilation. JPEN Journal of parenteral and enteral nutrition. 2017;41(8):1366-70.

8. MacLean AA, Alvarez NR, Davies JD, Lopez PP, Pizano LR. Complications of percutaneous endoscopic and fluoroscopic gastrostomy tube insertion procedures in 378 patients. Gastroenterology nursing : the official journal of the Society of Gastroenterology Nurses and Associates. 2007;30(5):337-41.

9. Hansen E, Qvist N, Rasmussen L, Ellebaek MB. Postoperative complications following percutaneous endoscopic gastrostomy are common in children. Acta paediatrica (Oslo, Norway : 1992). 2017;106(7):1165-9.

10.Collins JB, 3rd, Georgeson KE, Vicente Y, Hardin WD, Jr. Comparison of open and laparoscopic gastrostomy and fundoplication in 120 patients. Journal of pediatric surgery. 1995;30(7):1065-70; discussion 70-1.

11.Baker L, Beres AL, Baird R. A systematic review and meta-analysis of gastrostomy insertion techniques in children. Journal of pediatric surgery. 2015;50(5):718-25.

12.Cameron BH, Blair GK, Murphy JJ, 3rd, Fraser GC. Morbidity in neurologically impaired children after percutaneous endoscopic versus Stamm gastrostomy. Gastrointest Endosc. 1995;42(1):41-4.

13.Ackroyd R, Saincher M, Cheng S, El-Matary W. Gastrostomy tube insertion in children: the Edmonton experience. Can J Gastroenterol. 2011;25(5):265-8.

14.Lintula H, Juvonen P, Hamynen I, Heikkinen M, Eskelinen M. Severe gastro-oesophageal reflux necessitating fundoplication after percutaneous endoscopic and open gastrostomy in children. Langenbeck's archives of surgery. 2013;398(5):703-7.

15.Liu R, Jiwane A, Varjavandi A, Kennedy A, Henry G, Dilley A, et al. Comparison of percutaneous endoscopic, laparoscopic and open 
gastrostomy insertion in children. Pediatric surgery international. 2013;29(6):613-21 .

16.Durakbaşa ÇU, Okur H, Mutuş HM, Baş A, Sert M, Tosyalı A, et al. Çocuklarda perkütan endoskopik gastrostomi (PEG) uygulamalarının endikasyonları, komplikasyonları ve sonuçlarına ilişkin bir derleme. Çocuk Cerrahisi Dergisi. 2008;22(3):122-6. 